\title{
TOURIST PERCEPTIONS OF TOURISM AND ITS IMPLICATIONS FOR SUSTAINABLE TOURISM PLANNING
}

\author{
Yuthasak Chatkaewnapanon \\ Department of Tourism, Faculty of Humanities and Center of Tourism Research and Development, Chiang Mai \\ University, Thailand
}

\begin{abstract}
Tourism, theoretically, is perceived as either important for rural sustainability or major cause in host community impacts. Practically, tourism is also increasingly important as a cause for urbanization in many rural areas, particularly in developing countries including Thailand. Therefore, there are highly dynamic and interactive studies on the interaction between tourism and destination development. Tourism is not only to generate local economic, but also to change physical landscape of the area. Tourism has transformed an area into a tourist destination. However, overdevelopment of tourism industry can be resulted in no longer attract people to come. Therefore, understanding what tourists perceive as tourism attractiveness of the destination is important for guiding appropriate development. Regardless of taking sustainable tourism development concept into tourism planning consideration, ignoring to understand the holistic concept of tourism system can lead to the process of the perceived impacts of tourism on host communities. This is a conceptual paper attempts at raising an awareness of a destination attractiveness using tourist perceptions for sustainable tourism planning in rural Thailand. The conceptual framework is developed from existing theoretical and empirical research in the field of tourism studies. The paper has contributed to develop desired planning for sustainable tourism development in rural Thailand.
\end{abstract}

Keywords: Tourist perception, Tourism planning, Sustainability, Thailand

\section{INTRODUCTION}

Tourism as soft industry, it was once believed that less harmful to our livelihood. It is perceived as important for rural economic development. It is also increasingly important for urbanizing rural Thailand. However, tourism brings tourists to the destination areas. While it is to generate rural economic, it also changes physical landscape of the areas. Tourism has transformed an area into a tourist destination (Chatkaewnapanon 2012). It then has the potential to create direct impacts on any visiting location.

In response, various researches have been conducted to explain the results of uncontrolled tourism development in different locations. There are highly dynamic and interactive studies on the interaction between tourism and destination development. There are included the issues of both negative and positive economic, socio-cultural and physical aspects affected at host communities. Moreover, the alarms on those harmful effects on the host communities have led to new ways of thinking in protecting tourist destinations. Sustainable tourism development concept is then adopted to ensure the maintenance of environmental and social integrity within development process (Garcia-Rosell and Makinen 2013).

In recent years, the concept of sustainable tourism development has been widely discussed. Particularly, it has focused onto rural communities to minimize negative impacts (Sharpley 2009). In this essence, the concept aims to reconciling the rural livelihood and tourism development. To achieve the goal of sustainable community from tourism development requires the understanding of sustainability, tourism development and their component and relationships to a community (Garcia-Rosell and Makinen 2013). In other words, as issues of community and 
sustainability increase, it reflects on the importance of community participation in tourism development process.

Moreover, tourism research has explained extensively the interrelationship between tourist sustainability and community participation, which emphasizing on the process of quality of local participation (GarciaRosell and Makinen 2013). Without the effective of local participation, arguably, the community tourism development is doubted to be sustainable. Within this aspect, most research studies imply sustainable community tourism development into only the aspects of destination development. However, to make tourism development sustainable is not only keeping the community maintainable. In fact, along with the ensuring that a community does not live beyond its means, it is important to achieve, and to maintain an acceptable numbers of tourists. A community with no tourist cannot be examined within the concept of tourist destination development.

The paper argues that sustainable tourism development cannot be achieved when the focus is limited only within tourist destination development paradigms. In fact, it needs to include the analysis of its components surrounded the issue of tourism system. In other word, it needs to understand what the perceptions of tourists towards tourism development (Xu, Cui, Ballantye, and Packer 2013). This understanding will help to guide the development more precisely. Therefore, the aim of this paper is to propose the tourism system concept for a sustainable tourism development in rural Thailand. By understanding the demand side of tourism system, it will help guiding on planning tourism industry more sustainably.

\section{Sustainable tourism development: the discussion}

The adoption of the principle of sustainable development into a tourism context has been widely practiced with the idea of engaging and creating a balance between society, the environment and the tourism industry (Cawley and Gillmore 2008; GarciaRosell and Makinen 2013). In particular, Butler (1993: 29) one of the leading researchers in the area of Tourism Studies, defines tourism in context of sustainable development as:
Tourism which is developed and maintained in an area (community, environment) in such a manner, and at a scale that it remains viable over an indefinite period, and does not degrade or alter the environment (human and physical) in which it exists to such a degree that it prohibits the successful development and well-being of other activities and process.

Considering, the concept of sustainable tourism development aims to encourage economic growth and social development through tourism development while maintaining the environment. It has encouraged a revision in developmental thinking. Tourism economic development, therefore, acknowledges the ecological and social environment within its takes place (Mason 2008; Garcia-Rosell and Makinen 2013). However, to meet a point of sustainable tourism, economic growth is necessary in order to meet basic needs. Thus, tourism economic development should focus on the quality of economic growth rather than its quantity (Butler 1993).

The concept of sustainable tourism development has more focused onto particular areas to ensure that tourism development has minimized the environmental problems of destination areas. In other words, the concept is then a process of tourism development at destination areas in hopes of promoting economic developments and at the same time conserving local natural and cultural resources (Garcia-Rosell and Makinen 2013). To achieve such development, tourism activities need to consider locals and carrying capacity measure of the destination (Butler 1980). Therefore, in attempting to achieve sustainable tourism development, different aspects surrounding the issues of destination development have been suggested to be included in tourism development paradigms. There is, for instance, co-ordination of policies, tourism planning and local participations (Hall 2008; Mason 2008).

Tourism can create changes in values and system, traditional lifestyles, individual behavior and community structure (Chatkaewnapanon 2012; Tucker 2003). Thus, tourism research focuses on an increasing awareness of the dynamics, development processes and consequences for tourist destination and their population (Butler 1980; Cohen 2004; Cole 2008). In addition, the acknowledgement of a series of tourism development processes influences the 
social structure and the historical sequences of development in a destination resulted in Butler's tourism area lifecycle has been discussed worldwide (1980).

Butler's tourist area lifecycle model (1980), ever, since the concept created, it has led to a paradigm of destination development projects in examining the evolution of tourist destination within their conditions (Garay and Canoves 2011). While the tourist area lifecycle concept provides a tool by which the tourist stage of any destination can be evaluated, the concept has mellowed in its stated discussion only of a tourist destination. Therefore, sustainable tourism development regardless of it's attempting to include the perceptions of tourists towards a location $(\mathrm{Xu}$, Cui, Ballantyne and Packer 2013), coupled with the concept of tourist destination lifecycle is widely focused on only the well being of tourist destination.

\section{Community tourism development: a local aspect}

Tourism has proved to be one of the most ingeniously crafted, deliberately propagated and expedient opportunities for social exchange. Its philosophy enshrines some of the most ennobling aspirations of peace, enlightenment, self-actualization, social exchange, mutual understanding and learning. In principle, it is a remarkable largesse bequeathed upon humanity by humankind. At the same time, it has been a culprit of negative change, wherein destination environments have deteriorated, cultures changed and economics faltered. (Singh, Timothy and Dowling 2003: 3)

Tourism is, undoubtedly, a cause of the transition in many locations from a largely agricultural-based community to a contemporary tourism-based society (Chatkaewnapanon 2012; Huang 2013; Tucker 2003). Tourism is a mechanism in urbanization process in many remote and underdeveloped areas (Chatkaewnapanon 2012; Sharpley 2009; Tucker 2003). In this respect, tourist destinations are facing unexpected and uncontrolled changes. Major concerns have arisen about the potentially unfortunate effects of tourism on various aspects of the destinations (Moscardo, Konovaluv, Murphy and McGehee 2013).
Awareness of tourism development and their impacts on related areas has led to the growth of community approach towards sustainability (Okazaki 2008; Garcia-Rosell and Makinen 2013). To concern over the issue of local community selling their resources to tourists, the concept of community-based tourism (CBT) is introduced (Singh, Timothy and Dowling 2003). The concept is an alternative thinking towards achieving a sustainable tourism development (UNWTO 2008). CBT is a concept focusing on the ability of local community involved in tourism projects, particularly in rural areas. Actively participating in the development is a central focus to the concept (Simpson 2008). Therefore, CBT development strategy is based on community resources, needs and decisions. It aims to support livelihood, maintain biodiversity, stimulate SMEs, and reduce poverty (Okazaki 2008; Simpson 2008; UNWTO 2008). In other words, CBT is a concept created in hopes of achieving sustainable community tourism development.

CBT concept encourages the community to take control and management of their tourism industry for greater success of achieving sustainability (Choi and Sirakay 2006). In this respect, community participation is seen as the most important tool needed for the success of CBT. In fact, it is not a CBT project if a community lacks the desire to participate, control, manage and make decisions over their tourism industry (Tosun 2000). Therefore, involved with the community approach are two related concepts, participation and empowerment (Overton 1999). Both concepts are discussed the idea of concerning the locals as priorities in development process. Importantly, it is not only to make local participation more effective, but also to restore people the power to govern their own development (Overton 1999). Therefore, CBT has introduced as a promising alternative to conventional approaches to sustainable community tourism development. It is a holistic and inclusive process can lead to positive and permanent changes in host communities.

Considering, concept of sustainable tourism development in a community approach aims to reconciling the local livelihood in a tourism context (Sharpley 2009). The brief review has shown that sustainability is mainly defined and implemented as a guiding principle for tourism destination 
development. In other words, regardless of its widely practices, and concern over economic growth, mostly researches have been limiting their focus only on the quality of tourism destinations. Theoretically, the essence of the sustainable tourism development thinking should not be limited only on how to ensuring that a destination does not develop beyond its means. Or, the application of sustainability needs to go beyond only tourism products.

In fact, it is required to ensure that the broader concept of tourism system is instigated. This paper, therefore, argues that the challenge of the sustainable community tourism development is to find a way to apply the principle of tourism system to the practice of community tourism development.

\section{Tourism system}

To start tourism in a community requires a working process. The quality of the community in their attractions, infrastructure and facilities are necessary. Then tourism industry has a potential to be developed (McKercher and Ho2006; Graci 2008). Once it developed, to keep the community tourism running and working attractively is more challenging. Within this concern, sustaining tourism development in a community is not only to create tourism industry at a community, or to retain the quality of the destination, but all of those as well as to maintain the tourism industry in the community for the future generations. Therefore, this section discusses tourism system as a means to generate awareness, understanding and interest for the sustaining community tourism development.

According to Uysal (1998), the tourism system can be divided into two components, as origin and a destination. The origin refers to tourists, where the destination is a destination community. Tourism system is started off with a potential to be a tourist destination of any place. Moreover, to be developed into a tourist destination is a community with potential tourism products and adequate infrastructure and facilities. Those tourism products are natural and cultural resources, events and activities, handicrafts and souvenirs (Kresic and Prebezac 2011). Infrastructure and facilities are accommodation, road, transportation, and other services (Graci 2008).
On the other hand, tourists are those who come to the destination. In order to make them come, those tourism resources, infrastructure, and facilities need to be able to attract the potential tourists (Kresic and Prebezac 2011). Respectively, to attract tourists is to give them awareness of 'the attraction power and uniqueness of a destination' (Formica 2000: 22). In these forms of to attract them and to give them awareness can be explained within the push-pull theory. The attractiveness of the community is the pull factor to bring in tourists. The push factor refers to the perceived attractiveness of the place and the decision making of those tourists to travel to the destination (Formica 2000).

Therefore, the tourism system is the completed model of demand-supply (Leiper 1990). The supply side of the system, the community as a tourist destination, needs to be analyzed. At the same time, the potential tourists, as a demand segment, need to be market (Leiper 1990). Once the destination has been promoted to the market, it is up to the tourists to desire whether to go or not.

In fact, the tourism system will be completed when 'the destination area reaches people in the market and encourages them to travel' (Mill and Morison 1992: $\mathrm{xv})$. Then the question is how to create the holistic process. Formica (2000) emphasizes that the reinforcement of those segments to achieve the concept of tourism system is though the collaboration of the marketing travel link, where is refereed to travel agencies and tour operators.

Thus, to make the whole tourism system completed is to keep the two components interconnected. In this respect, a community needs to pull tourists into the area, at the same time, the tourists need to be pushed into the destination. Therefore, the model of tourism system is a cycle of a community and tourists, where it is within the linkage of push and pull theory.

\section{CONCLUSION: IMPLICATION OF TOURISM PLANNING}

The paper will bring back the discussion on sustainability back to the situation with which it began: the limitation of the interpretation. The implementations and focuses of sustainable tourism development arise in conditions of negative impacts of tourist destinations. As a result of to preserving the 
effected areas, defining or understanding the principle of sustainable development go directly to destination contexts. Moreover, other concepts such as tourist area lifecycle model, community-based tourism, local participation and empowerment are prescriptive approach to support the focus of sustainable tourism development on mainly only tourist destinations.

The paper is not questioning the desirable objective of sustainable tourism development. In fact, the concept of sustainable tourism development should not be directed into only the supply segment of tourism system. Along with the ensuring that a community should not live beyond its means, it is important to achieve, and to maintain an acceptable numbers of tourists. Therefore, the paper proposes the awareness of the holistic approach to achieve sustainable community tourism development.

\section{REFERENCES}

Butler, R., 1980, The concept of a tourism area cycle of evolution: implications for management of resources. Canadian Geographer, 24, 5-12

Butler, R., 1993, Tourism development in small islands: past influences and future directions. In: Tourism and the Environment: Regional, Economic and Policy Issues, edited by D.G. Drakakis-Smith and J. Schembri (Dordrecht: Kluwer Academic Publisher), pp. 71-91

Cawley, M. and Gillmore, D.A., 2008, Integrated rural tourism: concept and practice. Annals and Tourism Research, 35(2), 316-337

Chatkaewnapanon, Y., 2012, A Tourism History of Koh Samui, Thailand: Change and Adaptation in the Tourism Period (Saarbrucken: LAP Lambert Academic Publishing).

Choi, H.C. and Sirakaya, E., 2006, Sustainability indicators for managing community tourism. Tourism, 27, 1274-1289

Cole, S., 2008, Tourism, Culture, and Development: Hopes, Dreams and Realities in East Indonesia (Clevedon, Channel View Publications).

Formica, S., 2000, Destination attractiveness as a function of supply and demand interaction, Unpublished Doctoral Dissertation, the Virginia Polytechnic Institute and State University, Virginia

Garcia-Rosell, J. and Makinen, J., 2013, An integrative framework for sustainability evaluation in tourism: applying the framework to tourism product development in Finnish Lapland. Journal of Sustainable Tourism, 21(3), 396-416

Garay, L. And Canoves, G., 2011, Life cycles stages and tourism history: the Cataloni (Spain) experience. Annals of Tourism Research, 38(2), 651-671

Graci, S., 2008, Accommodating green: Examining barriers to sustainable tourism development. Department of Tourism and Environment, Brock University
Hall, C.M., 2008, Tourism Planning: Policies, Processes and Relationships (Essex: Pearson).

Huang, S.L., 2013, Visitor responses to the changing character of the visual landscape as an agrarian area becomes a tourist destination: Yilan County, Taiwan. Journal of Sustainable Tourism, 21(1), 154-171

Kresic, D. and Prebezac, D., 2011, Index of destination attractiveness as a tool for destination attractiveness assessment. Tourism, 59(4), 497-517

Leiper, N., 1990, Tourist Attraction Systems. Annals of Tourism Research, 17(3), 379-381

Mason, P., 2008, Tourism: Impacts, Planning and Management. London, Elsevier

Mckercher, B. and Ho, P.S.Y., 2006, Assessing the tourism potential of smaller cultural and heritage attractions. Journal of Sustainable Tourism, 14(5), 473-488

Mill, R.C. and Morrison, A.M., 1992, The Tourism System: An Introduction Text (New Jersey: Prentice-Hall International, Inc.)

Moscardo, G., Konovalov, E., Murphy, L. and Mcgehee, N., 2013, Mobilities, community well-being and sustainable tourism. Journal of Sustainable Tourism, 21(4), 532-556

Okazaki, E., 2008, A community-based tourism model: its conception and use. Journal of Sustainable Tourism, 16(5), 511-529

Overton, J., 1999, Sustainable development in the Pacific Islands. In: Strategies for Sustainable Development: Experiences from the Pacific, edited by J. Overton and R. Scheyyens (Sydney: University of New South Wales Press), pp. 1-15

Sharpley, R., 2009, Tourism Development and the Environment: Beyond sustainability? (London: Earthscan).

Simpson, M.C., 2008, Community benefit tourism initiatives - a conceptual oxymoron? Tourism Management, 29, 1-18

Singh, S., Timothy, D.J. and Dowling, R.K., 2003, Tourism and destination communities. In: Tourism in Destination Communities, edited by S. Singh, D.J. Timothy, and R.K. Dowling (Oxon: CABI Publishing), pp. 3-18

Tosun, C., 2000, Limits to community participation in the tourism development process in developing countries. Tourism Management, 21, 613-633

Tucker, H., 2003, Living with Tourism: Negotiating Identities in a Turkey Village (New York: Routledge)

United Nations World Tourism Organization (UNWTO). 2008. Tourism and Community Development: Asian Practices. Accessed October 5, 2015 from http://pub.unwto.org:81/wibRoot/Store/Shops/Infoshop/481 5/FCE2/5D45/7DF0/B4C5/C0A8/0164/248E/080425_com munity_development_asian_pracices_excerpt.pdf

Uysal, M., 1998, The determinants of tourism demand: a theoretical perspective. In: The Economic Geography of the Tourist Industry, edited by D. Ioanniades, K.G. Debbege (London: Routledge), pp. 79-98

Xu, H., Cui, Q., Ballantyne. R., and Packer, J., 2013, Effective environmental interpretation at Chinese natural attractions: the need for an aesthetic approach. Journal of Sustainable Tourism, 21(1), 117-133 